\title{
APPLICATION OF HULL-LESS BARLEY VARIETY 'KORNELIJA' GRAINS FOR YOGURT DEVELOPMENT
}

\author{
Diāna Dancīte ${ }^{1}$, Jeḷena Zagorska ${ }^{2, \#}$, Tatjana K̦ince ${ }^{2}$, and Vita Šterna ${ }^{3}$ \\ 1 "SIA Orkla Latvija", 22 Miera Str., Rīga, LV-1001, LATVIA \\ ${ }^{2}$ Faculty of Food Technology, Latvia University of Life Sciences and Technologies, 22 Rīgas Str., Jelgava, LV-3004, LATVIA \\ ${ }^{3}$ Department of Plant Breeding and Agroecology, Institute of Agricultural Resources and Economics, \\ 14 Struktoru Str., Rīga, LV-1039, LATVIA \\ \# Corresponding author, jelena.zagorska@Ilu.lv
}

Contributed by Tatjana K̦ince

\begin{abstract}
Nowadays consumers are looking for new food products with added nutritional value. Therefore, producers and scientists develop new recipes and technologies with the aim to enrich products with fibres, vitamins, and probiotics. Since naked barley contains high concentration of soluble dietary fibre, including $\beta$-glucans, which have stabilising properties, it has a good potential for fermented dairy food development. The goal of the current study was to assess the application of hull-less barley grain 'Kornelija' for development of fibre-enriched yogurt. Milk was fermented with freeze-dried starter (Lactobacillus delbrueckii ssp. bulgaricus, Streptococcus thermophilus) by adding flour of ungerminated, 24 and 36 hours germinated barley grain (amount 2\%, 3\%, 4\%) at $41 \pm 1^{\circ} \mathrm{C}$ up to $\mathrm{pH} 4.7 \pm 1.0$. $\mathrm{pH}$ of samples during fermentation, the colony forming units of lactic acid bacteria, viscosity, and concentration of fibres were determined. Results of the current study showed that flour from ungerminated, and 24 and 36 hours germinated barley grain, fortified yogurt with dietary fibre (from 0.89 to $1.77 \mathrm{~g} \cdot 100 \mathrm{kcal}^{-1}$ ), promoted growth of lactic acid bacteria in the product, increased the viscosity and shortened fermentation time, but the significance of effects depended on the amount and type of added flour.
\end{abstract}

Key words: lactic acid bacteria, viscosity, fibres, germinatio.

\section{INTRODUCTION}

Nowadays consumers are looking for new food products with added nutritional value. Producers and scientists develop new recipes, combining ingredients and technologies with the aim to enrich products with fibres, vitamins, preand probiotics etc. The World and Health Organisation (WHO) predicts that by 2030 cardiovascular diseases will continue to be the main cause of death and will affect around 23.6 million people worldwide (Rushdy Mohamed et al., 2017). Increased low-density serum cholesterol is a risk factor for cardiovascular diseases such as atherosclerosis, stroke and coronary heart disease. There is an increasing interest among consumers in the consumption of functional products, including those that improve serum cholesterol dynamics.

The analysis of the market for functional products points to their gradual and sustainable growth, resulting in a new functional and healthy product development. Fibres, vitamins, and minerals are the most important nutrients in functional products, which occupy most of the global food markets. Dairy products, followed by cereal products take up the largest market share of functional products (Fernandez and Marette, 2018; González et al., 2019).

Increase of nutritional value and use of new technologies in the production of innovative products, changing composition of products and bringing them closer to needs of human body are modern product production trends (Zubillaga et al., 2001; Grajek et al., 2005). Fermented dairy products containing probiotic bacteria help to ensure the balance of "necessary" and "undesirable" micro-organisms in the gut. The effects of probiotic bacteria on lowering the cholesterol level in plasma have been studied in recent years (Hashemi Gahruie et al., 2015). The recommended dose of fermented dairy products (yogurt, kefir) is at least $220 \mathrm{~g}$ per day (Fernandez and Marette, 2018). 
Milk is rich in various nutrients (proteins, vitamins, calcium, and others), but there is no fibre. Fibre from different sources could be added to dairy products with the aim to enrich the range of nutrients, considering their water binding capacity, improving structure of the yogurt. Fibre rich products reduce hypertension, obesity, gastrointestinal disorders, coronary heart disease, diabetes and oncological diseases (Kalra and Jood, 2001; Shah et al., 2017; Martínez-Subirà et al., 2020). Enrichment of yogurt or other dairy products with fibre generates an increased interest in the development of functional products in order to provide a favourable effect on consumer health (Fazilah et al., 2018). A study on the effects of dietary fibres on the quality of yogurt showed that $1.32 \%$ of the oat fibre additive for unsweetened yogurt improved its structure, texture and taste (Hashemi Gahruie et al., 2015).

$\beta$-glucans and phenolic compounds have been identified as powerful tools for the prevention and treatment of heart diseases, diabetes, inflammatory intestines and other diseases. Increased levels of total fibre and soluble fibre like $\beta$-glucans (recommended daily intake is $3 \mathrm{~g}$ ) (Liutkevičius et al., 2015) in food can reduce the cholesterol level in human blood (Havrlentová and Kraic, 2006; El Khoury et al., 2012), which contributes to the prevention of cardiovascular disease. $\beta$-glucans have a strong bifidogenic effect, contribute to the prevention of intestinal diseases, probably strengthening of the immune system, favourable modulating of the gut microbiome, and reinforcing of the intestinal barrier (Martínez-Subirà et al., 2020). Hull-less barley grain has the ability to lower the glycaemic index, which is favourable for diabetic patients (Jenkins et al., 2002; Meija et al., 2019).

The cereals of the hull-less barley variety 'Kornelija' have a unique chemical composition and excellent dietary value (Sterna et al., 2019). Thus, the use of grains or flour of this variety in the manufacture of foods provides a significantly higher protein, $\beta$-glucans, and phenolic compound concentration and their antioxidant composition compared to other cereal species. The high nutritional value of hull-less barley 'Kornelija' combined with a dairy product - yogurt, make it possible to obtain a high nutritional product that will contribute to the health of consumers.

The goal of the current study was to assess the application of hull-less barley grain 'Kornelija' for development of fibre-enriched yogurt.

\section{MATERIALS AND METHODS}

Materials. The following materials were used in the study: milk $2.0 \%$ (Marge, Poland), flour made from grains of hull-less barley 'Kornelija' (Hordeum vulgare), freeze-dried starter Yo-Flex YF-L811 (LTD Chr. Hansen, Denmark, composition: Lactobacillus delbrueckii ssp. bulgaricus, Streptococcus thermophilus).

Grain preparation (germination) for obtaining flour. Grain was washed and soaked in water (proportion 1:2) at
$22 \pm 2{ }^{\circ} \mathrm{C}$ for $24 \pm 1 \mathrm{~h}$. After soaking, the grain was placed for germination in a climate chamber OF ICH110 (Memmert, Germany) at $35 \pm 1{ }^{\circ} \mathrm{C}$ and in relative humidity (RH) $95 \pm 5 \%$ in darkness for $24 \pm 1 \mathrm{~h}$ and $36 \pm 1 \mathrm{~h}$ (Kince et al., 2017). After germination, the grain was dried at $60 \pm$ $2{ }^{\circ} \mathrm{C} 7 \pm 1 \mathrm{~h}$ (Gan et al., 2018) in a cabinet drier UF160 till moisture content $13 \pm 2 \%$ (Memmert, Germany).

Flour production. Dried germinated, as well as ungerminated grain was ground in a laboratory mill 3100 (Perten, Sweden) to obtain fine whole grain flour.

Yogurt production. Yogurt was produced according to a standard technology using a freeze-dried starter Yo-Flex YF-L811 and adding ungerminated, 24 and 36 hours germinated hull-less barley 'Kornelija' grain flour in the following amounts: $2 \%, 3 \%$, and $4 \%$. Milk was fermented at $41 \pm$ $1{ }^{\mathrm{O}} \mathrm{C}$ up to $\mathrm{pH} 4.7 \pm 1.0$. Then, the yogurt was matured and stored at $6 \pm 1{ }^{\circ} \mathrm{C}$ for 24 hours before analysis.

Quality parameters of barley grains were determined using standard methods: total dietary fibres (AOAC 991.43:1994), $\beta$-glucan (ICC Standard Method No. 168 for assessing mixed-linkage $\beta$-glucans by using Megazyme Assa Kits.), proteins (ISO 8968-1:2014), fat (ISO 6492:1999), and sugars (PB-79/HPLC ed. V of 18.05.2017).

Quality parameters of yogurt. $\mathrm{pH}$, lactic acid bacteria colony forming units (CFU) and viscosity of yogurt were evaluated. $\mathrm{pH}$ was detected according to LVS ISO 5546:2010 using a pH-meter (JENWAY 3520, Mettler Toledo, Switzerland), and lactic acid bacteria CFU according to LVS ISO 15214:1998, using MRS agar (Scharlab, S., L., Spain).

Viscosity was measured using a DV-III Ultra Programmable Rheometer (Brookfield Engineering Laboratories Inc., USA). Yogurt after $24 \mathrm{~h}$ storage at $6 \pm 1{ }^{\circ} \mathrm{C}$ was transferred into a small sample holder. Rotation speed of the SC4-16 spindle was set at $10 \mathrm{~min}^{-1}$. Data was recorded in the Rheocalc V2.6.: Rheometer programme $10 \mathrm{~s}$ after beginning of spindle rotation. Viscosity was measured five times using a new yogurt sample each time.

Data processing. Mean values and standard deviations were calculated. ANOVA and the Tukey test were used for analysis of results. A $p$-value 0.05 was considered significant. Data was processed with MS Excel 2016 and SPSS 19.0 programmes. The results were determined in triplicate.

\section{RESULTS}

$\beta$-glucan promotes lactic acid bacteria growth and acts as a prebiotic in different products (Gee et al., 2007). Sugar content and composition is another factor affecting lactic acid bacteria growth. Glucose and fructose act as nutrients for microorganism development and therefore its concentration in grain is vitally important for obtaining fermented product. Therefore, the chemical composition of grain and 
changes during germination were evaluated. The chemical composition of ungerminated and germinated grain flour is given in Table 1.

The concentration of glucose and fructose significantly $(p<$ 0.05 ) increased in barley grain during germination, while the concentration of total dietary fibres, including $\beta$-glucan, decreased, depending on time of germination $(p<0.05)$.

Concentration of $\beta$-glucan in yogurt samples is shown in Table 2. Addition of hull-less barley flour to the milk before fermentation promoted a significant $(p<0.05)$ increase of $\beta$-glucan concentration in yogurt, from 0 in the control sample to $1.1 \mathrm{~g} \cdot 100 \mathrm{~g}^{-1}$ in the $3 \%$ ungerminated grain flour samples.

During fermentation, $\mathrm{pH}$ was controlled in yogurt samples (see Fig. 1). There was a larger decrease of $\mathrm{pH}$ and shorter fermentation time in samples with germinated hull-less barley flour in different amounts comparing to the control sample. Similar results were observed in a study with oats additive, reach in $\beta$-glucans (Liutkevičius et al., 2015).

Table 1. Chemical composition of barley grain 'Kornelija' flour

\begin{tabular}{l|c|c|c}
\hline \multirow{2}{*}{ Parameter } & \multicolumn{3}{|c}{ Value, g. $100 \mathrm{~g}^{-1}$} \\
\cline { 2 - 4 } & ungerminated & 24 -h germinated & 36 -h germinated \\
\hline Dietary fibres & $26.3 \pm 1.5 \mathrm{a}$ & $25.8 \pm 1.6 \mathrm{a}$ & $24.6 \pm 1.2 \mathrm{a}$ \\
Including & $4.8 \pm 0.3 \mathrm{a}$ & $4.1 \pm 0.3 \mathrm{~b}$ & $3.8 \pm 0.2 \mathrm{c}$ \\
$\quad \beta$-glucan & & & \\
Proteins & $13.5 \pm 0.7 \mathrm{a}$ & $14.5 \pm 0.9 \mathrm{a}$ & $14.3 \pm 0.7 \mathrm{a}$ \\
Lipids & $2.4 \pm 0.1 \mathrm{a}$ & $2.4 \pm 0.1 \mathrm{a}$ & $2.3 \pm 0.1 \mathrm{a}$ \\
Starch & $58.6 \pm 2.9 \mathrm{a}$ & $58.0 \pm 3.1 \mathrm{a}$ & $55.9 \pm 2.8 \mathrm{~b}$ \\
Total sugars: & $1.00 \pm 0.20 \mathrm{a}$ & $3.00 \pm 0.30 \mathrm{~b}$ & $3.20 \pm 0.30 \mathrm{~b}$ \\
$\quad$ Glucose & $0.30 \pm 0.05 \mathrm{a}$ & $0.50 \pm 0.10 \mathrm{~b}$ & $0.90 \pm 0.10 \mathrm{c}$ \\
Fructose & $<0.20 \mathrm{a}$ & $0.30 \pm 0.10 \mathrm{~b}$ & $0.40 \pm 0.19 \mathrm{c}$ \\
Sucrose & $0.74 \pm 0.15 \mathrm{a}$ & $1.20 \pm 0.10 \mathrm{~b}$ & $1.90 \pm 0.20 \mathrm{c}$ \\
Maltose & $<0.20 \mathrm{a}$ & $1.00 \pm 0.10 \mathrm{~b}$ & $<0.20 \mathrm{c}$
\end{tabular}

Results expressed as means \pm standard deviation. Different letters in the same line represent statistically different results $(p<0.05)$.

Table 2. Concentration of fibre in yogurt samples

\begin{tabular}{c|c|c|c}
\hline $\begin{array}{c}\text { Germination } \\
\text { time, } \mathrm{h}\end{array}$ & $\begin{array}{c}\text { Amount } \\
\text { of flour }\end{array}$ & $\begin{array}{c}\text { Fibre, } \\
\mathrm{g} \cdot 100 \mathrm{~g}^{-1}\end{array}$ & Fibre $100 \mathrm{kcal}^{-1}$ \\
\hline 0 & $\mathrm{~K}$ & $0.0 \mathrm{a}$ & $0.0 \mathrm{a}$ \\
0 & $2 \%$ & $0.5 \mathrm{~b}$ & $0.89 \mathrm{~b}$ \\
0 & $3 \%$ & $0.8 \mathrm{c}$ & $1.35 \mathrm{~d}$ \\
0 & $4 \%$ & $1.1 \mathrm{~d}$ & $1.77 \mathrm{e}$ \\
24 & $2 \%$ & $0.5 \mathrm{a}$ & $0.89 \mathrm{~b}$ \\
24 & $3 \%$ & $0.8 \mathrm{~b}$ & $1.35 \mathrm{~d}$ \\
24 & $4 \%$ & $1.0 \mathrm{c}$ & $1.61 \mathrm{e}$ \\
36 & $2 \%$ & $0.5 \mathrm{a}$ & $0.89 \mathrm{~b}$ \\
36 & $3 \%$ & $0.7 \mathrm{~b}$ & $1.18 \mathrm{c}$ \\
36 & $4 \%$ & $1.0 \mathrm{c}$ & $1.61 \mathrm{e}$
\end{tabular}

Results expressed as means \pm standard deviation. Different letters in the same column represent statistically different results $(p<0.05)$.
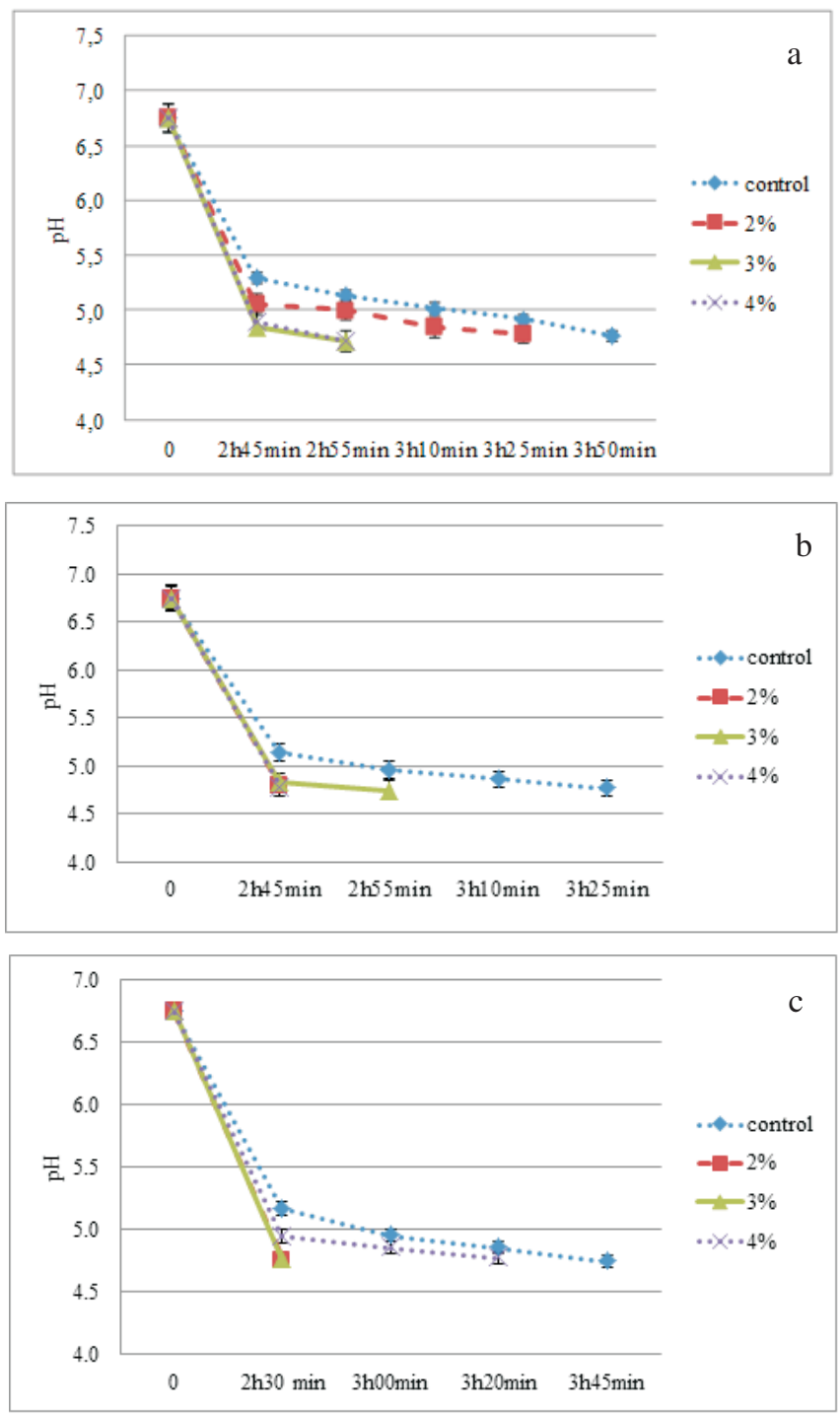

Fig. 1. pH changes during fermentation in yogurt: a, ungerminated grain; b, 24-h germinated grain; c, 36-h germinated grain.

The lactic acid bacteria count in yogurt samples is shown in Figure 2.

The CFU of lactic acid bacteria, determined according to Republic of Latvia Minister Cabinet Regulation No. 97 "Regulations on Classification, Quality, and Labelling Requirements for Dairy Products", in all analysed samples was above $7 \log \mathrm{CFU} \mathrm{ml} \mathrm{m}^{-1}$.

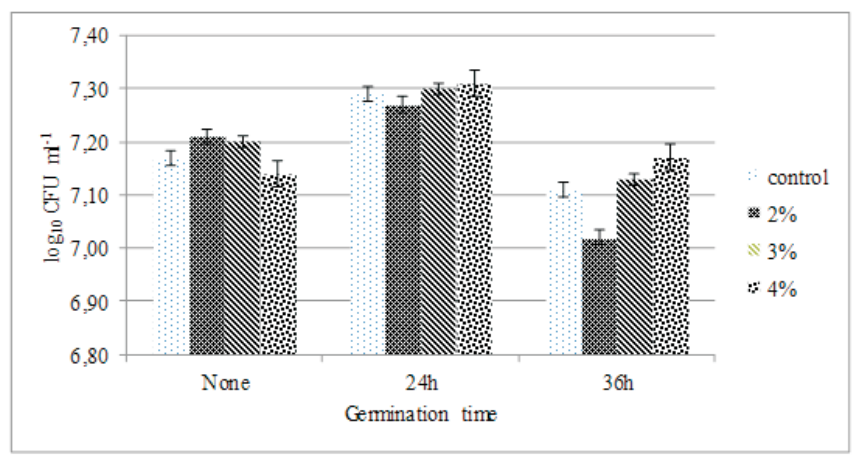

Fig. 2. Lactic acid bacteria CFU in yogurt samples. 
More intensive lactic acid bacteria growth was observed in samples with $2 \%$ and $3 \%$ ungerminated barley flour, and the highest in $4 \%$ ungerminated barley flour samples.

In control samples, the lactic acid bacteria CFU was higher comparing to the samples with 24-h germinated $2 \%$ grain flour additions, but the difference was not significant $(p<$ 0.05). Increasing the amount of barley flour gave a positive effect on lactic acid bacteria growth, as samples with $3 \%$ and $4 \%$ of barley flour had a higher CFU than in the control and sample with $2 \%$ of barley flour. Such results are in agreement with previous work (Arena et al., 2014) on barley flour suitability for lactic acid bacteria growth. The same tendency was observed in samples with flour from 36-h germinated grains, but the bacteria count was significantly lower than in samples with $24 \mathrm{~h}$ germinated grain flour.

Previous studies indicated, that $\beta$-glucan can promote higher viscosity of fermented dairy products (Shah et al., 2017; Xiao et al., 2020; Zhao, Fu, and Li, 2020). The results on yogurt viscosity are shown in Figure 3. Significantly higher $(p<0.05)$ viscosity was observed in samples with $3 \%$ and $4 \%$ ungerminated barley grain flour additions.

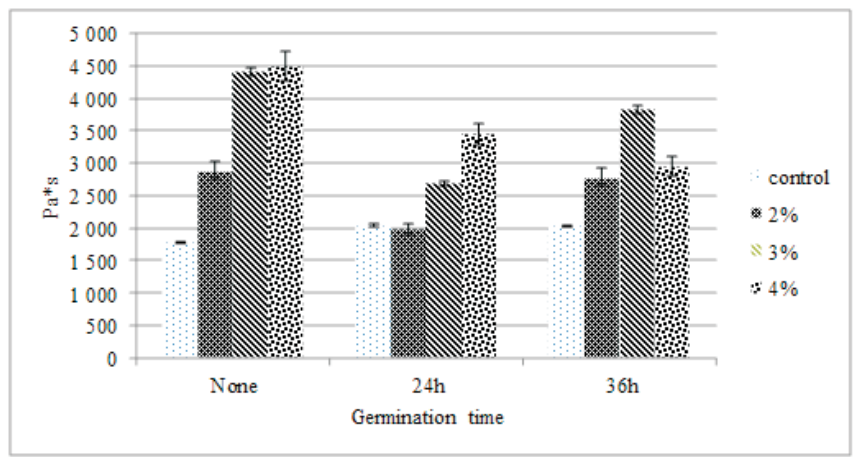

Fig. 3. Viscosity of yogurt samples.

Samples with germinated grain flour with $3 \%$ and $4 \%$ of barley grain flour showed some significant differences $(p<$ $0.05)$. Viscosity significantly increased with addition of germinated barley grain flour, except in the samples with $4 \%$ addition of 36-h germinated barley grain flour. Comparing samples with differently prepared barley grain flour additions, better results (higher viscosity) were obtained in samples with ungerminated barley grain flour and higher concentration of $\beta$-glucan (see Table 2).

\section{DISCUSSION}

Many biological changes occur in the grain during germination: hydrolysis of starch by $\alpha, \beta$ amylase, resulting in increased concentration of sugars; hydrolysis of proteins to peptides and amino acids, including changes in amino acids composition; hydrolysis of triglyceride and changes in saturated and unsaturated fatty acids ratios. Increased amount of bioactive compounds and antioxidants occurs in germinated grains (Lee et al., 2020).
Germination promotes hydrolysis of $\beta$-glucan in grain (in barley and in oats). A significant reduction $(p<0.05)$ of $\beta$-glucan concentration occurs during germination (more than 24 h) (Hübner et al., 2010; Gan et al., 2018). Similar results were found in the current study, and even $24 \mathrm{~h}$ after germination a significantly $(p<0.05)$ lower $\beta$-glucan concentration was observed.

Addition of hull-less barley flour to yogurt raises its nutritional properties, since dairy products have no fibre. Presence of $\beta$-glucan in yogurt can improve health when used in the diet. According to Regulation (EC) No. 1924/2006 on nutritional and health claims made on foods, yogurt samples with germinated and ungerminated grain flour (4\%) are a "source of fibre".

Insoluble fibre has no effect on lactic acid bacteria growth during fermentation, while soluble fibre (main representative $\beta$-glucan) contributes to microorganism development in yogurt and increases viscosity of the product (Gee et al., 2007; Lee et al., 2020). Various studies have shown that the enrichment of milk with dietary fibre, in particularly with $\beta$-glucans, contributes to faster growth of lactic acid bacteria (Raikos et al., 2018). One more factor stimulating bacteria growth is the presence of monosaccharides in the substrate. In the current study more intensive lactic acid bacteria growth was observed in samples with ungerminated and 24-h germinated grain flour. It can be concluded that $\beta$-glucan concentration has a more significant effect on lactic acid bacteria growth, since the lowest bacteria counts occurred in samples with the highest sugar and lowest $\beta$-glucan concentrations (36-h germinated grain flour). The use of barley as a $\beta$-glucan source results in a pronounced bifidogenic effect on health of elderly people, indicating its potential as a prebiotic source (Mitsou et al., 2010) in products containing Bifidobacterium.

Comparing proportion of barley grain flour, a hastened $\mathrm{pH}$ decrease was observed in samples with greater flour additions $-3 \%$ and $4 \%$ flour. This indicates that the activity of lactic acid bacteria in yogurt was promoted by the presence and amount of barley flour.

The results indicated the effect of amount of barley flour on the development of lactic acid bacteria differed in the case of ungerminated grains; $2 \%$ and 3\% flour addition gave better results, while for germinated grains $4 \%$ flour addition could be recommended, since concentration of $\beta$-glucan in grain during germination decreased (see Table 1). Previous work (Lee et al., 2020) showed that $\beta$-glucan promotes lactic acid bacteria growth and has potential as a prebiotic in functional food production. Yogurt enriched with $\beta$-glucan should be given considerable attention as it has a positive effect on human microbiota composition. Furthermore, for some specific strains of lactic acid bacteria, recovery of growth after oro-gastrointestinal stress was significantly faster when $\beta$-glucan-containing substrates were used (Arena et al., 2014). 
Our results demonstrated that the use of ungerminated barley in fermentation significantly increased $(p<0.05)$ the viscosity of yogurt samples, and samples with highest amount of barley flour had higher viscosity. A possible explanation for this is the ability of water soluble polysaccharides to link water and interact with dairy proteins by increasing molar mass and formation of a gel structure (Raikos et al., 2018). Since, hull-less barley contains high concentration of $\beta$-glucans and other soluble dietary fibre, it is considered as a natural thickener substitute, and has good potential for promoting viscosity in fermented dairy products, such as yogurt.

Use of germinated (24-h and 36-h) grain flour in yogurt fermentation had a positive effect on viscosity as well, but the effect was significantly $(p<0.05)$ lower than for ungerminated grain flour. Such results can be explained by the significantly $(p<0.05)$ lower $\beta$-glucan concentration in germinated grain flour (see Table 1).

Summarising the study results, hull-less barley 'Kornelija' has potential as an additive for yogurt production, promoting lactic acid bacteria growth, increasing viscosity and providing nutritional value (enrichment with soluble $\beta$-glucan) of the product.

\section{CONCLUSIONS}

Results of the current study showed that ungerminated, 24and 36-hour germinated barley grain flour can be successfully used in yogurt production.

Addition of ungerminated barley grain flour (2\%, 3\%) promotes lactic acid bacteria growth and higher viscosity of the yogurt. During germination, $\beta$-glucan concentration decreased, and therefore samples with germinated (24-h, 36-h) barley grain flour better results (lactic acid bacteria count and viscosity) than for samples with higher amounts of flour $(4 \%)$.

The health claim "source of fibre" can be applied for yogurt samples with addition of $4 \%$ ungerminated and germinated barley grain flour.

\section{REFERENCES}

Arena, M. P., Caggianiello, G., Fiocco, D., Russo, P., Torelli, M., Spano, G., Capozzi, V. (2014). Barley $\beta$-glucans-containing food enhances probiotic performances of beneficial bacteria. Int. J. Mol. Sci., 15 (2), 3025-3039.

El Khoury, D., Cuda, C., Luhovyy, B. L., Anderson, G. H. (2012). Beta glucan: Health benefits in obesity and metabolic syndrome. J. Nutr. Metab., 2012, 851362.

Fazilah, N. F., Ariff, A. B., Khayat, M. E., Rios-Solis, L., Halim, M. (2018). Influence of probiotics, prebiotics, synbiotics and bioactive phytochemicals on the formulation of functional yogurt. J. Funct. Foods, 48, 387-399.

Fernandez, M. A., Marette, A. (2018). Novel perspectives on fermented milks and cardiometabolic health with a focus on type 2 diabetes. Nutr. Rev., 76, 16-28.

Gan, R. Y., Chan, C. L., Yang, Q. Q., Li, H. Bin, Zhang, D., Ge, Y. Y., Gunaratne, A., Gr, J., Corke, H. (2018). Bioactive compounds and benefi- cial functions of sprouted grains. In: Feng, H., Nemzer, B., De Vries, J. W. (eds.) Sprouted Grains: Nutritional Value, Production, and Applications. Woodhead Publishing and AACC International Press, pp. 191-246.

Gee, V. L., Vasanthan, T., Temelli, F. (2007b). Viscosity of model yogurt systems enriched with barley $\beta$-glucan as influenced by starter cultures. Int. Dairy J., 17 (9), 1083-1088.

González, S., Fernịndez-Navarro, T., Arboleya, S., De Los Reyes-Gavilán, C. G., Salazar, N., Gueimonde, M. (2019). Fermented dairy foods: Impact on intestinal microbiota and health-linked biomarkers. Frontiers Microbiol., 10, https://doi.org/10.3389/fmicb.2019.01046

Grajek, W., Olejnik, A., Sip, A. (2005). Probiotics, prebiotics and antioxidants as functional foods. Acta Biochim. Polon., 52 (3), 665-671.

Hashemi Gahruie, H., Eskandari, M. H., Mesbahi, G., Hanifpour, M. A (2015). Scientific and technical aspects of yogurt fortification: A review. Food Sci. Hum. Wellness, 4 (1), 1-8.

Havrlentová, M., Kraic, J. (2006). Content of $\beta$-D-glucan in cereal grains. J. Food Nutr. Res., 45 (3), 97-103.

Hübner F., O`Neil T., Cashman K. D., Arendt, E. K. (2010). The influence of germination conditions on beta-glucan, dietary fibre and phytate during the germination of oats and barley. Eur. Food Res. Technol., 231, 27-35.

Jenkins A. L., Jenkins D. J. A., Zdravkovic U., Wursch P., Vuksan, V. (2002). Depression of the glycaemic index by high levels of beta-glucan fiber in two functional foods tested in type 2 diabetes. Eur. J. Clin. Nutr., 56, $622-628$.

Kalra, S., Jood, S. (2001). Effect of dietary barley $\beta$-glucan on cholesterol and lipoprotein fractions in rats. J. Cereal Sci., 31, 141-145.

Kince, T., Galoburda, R., Klava, D., Tomsone, L., Senhofa, S., Straumite, E., Kerch, G., Kronberga, A., Sturite, I., Kunkulberga, D., B. A. (2017). Breakfast cereals with germinated cereal flakes: changes in selected physical, microbiological, and sensory sharacterictics during storage. Eur. Food Res. Technol., 243, 1497-1506.

Lazaridou, A., Serafeimidou, A., Biliaderis, C. G., Moschakis, T., Tzanetakis, N. (2014). Structure development and acidification kinetics in fermented milk containing oat $\beta$-glucan, a yogurt culture and a probiotic strain. Food Hydrocolloids, 39, 204-214.

Lee, J. M., Jang, W. J., Lee, E. W., Kong, I. S. (2020). $\beta$-glucooligosaccharides derived from barley $\beta$-glucan promote growth of lactic acid bacteria and enhance nisin Z secretion by Lactococcus lactis. LWT, 122, 109014.

Liutkevičius, A., Speiciene, V., Alencikiene, G, Miželiene, A., Kaminskas, A., Abravičius, J. A., Vitkus, D., Jablonskiene, V. (2015). Oat $\beta$-glucan in milk products: Impact on human health. Agricult. Food, 3, 74-81.

Martínez-Subirà, M., Romero, M. P., Puig, E., Macià, A., Romagosa, I., Moralejo, M. (2020). Purple, high $\beta$-glucan, hulless barley as valuable ingredient for functional food. $L W T, \mathbf{1 3 1}, 109582$

Meija, L., Havensone, G., Lejnieks, A. (2019). Postprandial glycaemic and insulinaemic responses after consumption of activated wheat and triticale grain flakes. J. Nutr. Metab., 2019, 6594896.

Mitsou, E. K., Panopoulou, N., Turunen, K., Spiliotis, V., Kyriacou, A (2010). Prebiotic potential of barley derived $\beta$-glucan at low intake levels: A randomised, double-blinded, placebo-controlled clinical study. Food Res. Int., 43 (4), 1086-1092.

Raikos, V., Grant, S. B., Hayes, H., Ranawana, V. (2018). Use of $\beta$-glucan from spent brewer's yeast as a thickener in skimmed yogurt: Physicochemical, textural, and structural properties related to sensory perception. J. Dairy Sci., 101 (7), 5821-5831.

Rushdy Mohamed, A., Raafat, M. E., Mahmoud, Abd-Alhameid, A., Mohamed Fawzy, R. (2017). Hypocholesterolaemic effect of probiotic yogurt enriched with barley $\beta$-glucan in rats fed on a high-cholesterol diet. Mediterr. J. Nutr. Metab., 10 (1), 1-12. 
Shah, A., Gani, A., Masoodi, F. A., Wani, S. M., Ashwar, B. A. (2017). Structural, rheological and nutraceutical potential of $\beta$-glucan from barley and oat. Bioactive Carbohydr. Dietary Fibre, 10, 10-16.

Sterna, V., Kunkulberga, D., Straumite, E., Bernande, K. (2019). Naked barley influence on wheat bread quality. In: FoodBalt 2019: Proceedings of $13^{\text {th }}$ Baltic Conference on Food Science and Technology "Food. Nutrition. Well-Being”. Jelgava, Latvia, 2-3 May 2019, Jelgava, pp. 98-102.

https://llufb.llu.lv/conference/foodbalt/2019/FoodBalt_2019_proceedings.pdf (accessed 10.11.2021).

Received 22 March 2021

Accepted in the final form 7 November 2021
Xiao, X., Tan, C., Sun, X., Zhao, Y., Zhang, J., Zhu, Y., Bai, J, Dong, Y., Zhou, X. (2020). Effects of fermentation on structural characteristics and in vitro physiological activities of barley $\beta$-glucan. Carbohydrate Polymers, 231, 115685 .

Zhao, Y., Fu, R., Li, J. (2020). Effects of the $\beta$-glucan, curdlan, on the fermentation performance, microstructure, rheological and textural properties of set yogurt. $L W T, \mathbf{1 2 8}, 109449$.

Zubillaga, M., Weill, R., Postaire, E., Goldman, C., Caro, R., Boccio, J. (2001). Effect of probiotics and functional foods and their use in different diseases. Nutr. Res., 21 (3), 569-579.

\section{KAILGRAUDU MIEŽU ŠKYIRNES 'KORNELIJA' GRAUDU IZMANTOŠANA JOGURTA IZSTRĀDĒ}

Mūsdienās pircēji meklē un pievērš aizvien lielāku uzmanību jauniem pārtikas produktiem ar paaugstinātu uzturvērtību. Tāpēc ražotāji un zinātnieki izstrādā jaunas receptūras un tehnoloğijas ar mērḳi bagātināt produktus ar šḳiedrvielām, vitamīniem un probiotikām. N̦emot vērā, ka kailgraudu mieži ir bagāti ar $\beta$-glikāniem un citām šķ̄stošām šķiedrvielām, tiem ir liels potenciāls jaunu, veselīgu skābpiena produktu ražošanā. Zinātniskā darba mērḳis bija izvērtēt kailgraudu miežu šḳirnes 'Kornelija' izmantošanas iespējas jogurta izstrādē. Jogurts tika raudzēts, izmantojot liofilizētu ieraugu (Lactobacillus delbrueckii ssp. bulgaricus, Streptococcus thermophilus), pievienojot miltus no nediedzētiem, 24 h, 36 h diedzētiem miežiem (koncentrācijās: $2 \%, 3 \%, 4 \%$ ). Piens tika raudzēts $41 \pm 1{ }^{\circ} \mathrm{C}$ līdz pH $4.7 \pm 1.0$. Raudzēšanas laikā tika analizēts pienskābes baktēriju skaits, viskozitāte un šķiedrvielu saturs produktā. Pētījuma rezultāti parāda, ka milti no nediedzētiem, 24 h, 36 h diedzētiem kailgraudu miežiem, bagātina jogurtu ar škiedrvielām (no 0.89 līdz 1.77 g škiedrvielu $100 \mathrm{kcal}^{-1}$ ), veicina pienskābes baktēriju attīstību, palielina produkta viskozitāti un saīsina raudzēšanas laiku, bet izmaiņu būtiskums ir atkarīgs no pievienoto miltu veida un daudzuma. 